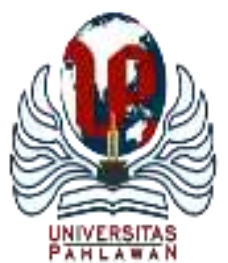

Edukatif : Jurnal Ilmu Pendidikan Volume 3 Nomor 6 Tahun 2021 Halm 5005 - 5016

EDUKATIF: JURNAL ILMU PENDIDIKAN

Research \& Learning in Education

https://edukatif.org/index.php/edukatif/index

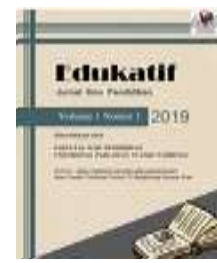

\title{
Pengembangan Media Audio Visual Situs Peninggalan Sejarah Kolonialisme Inggris di Kota Bengkulu untuk Siswa Sekolah Dasar
}

\author{
Panut Setiono $^{1 凶}$, Atika Susanti ${ }^{2}$, Nabila Khansa Putri ${ }^{3}$, Mufidah Mahdiyah ${ }^{4}$, \\ Anis Fahmi Andini ${ }^{5}$ \\ Program Studi Pendidikan Guru Sekolah Dasar, Universitas Bengkulu, Indonesia ${ }^{1,2,3,4,5}$ \\ E-mail : setiono.pgsd@unib.ac.id ${ }^{1}, \underline{\text { atikasusanti@unib.ac.id }}^{2}$, nabila.khansa.putri14@gmail.com $^{3}$, \\ mufidahmahdiyah93@gmail.com ${ }^{4}, \underline{\text { anis.fahmi25@ gmail.com }}^{5}$
}

\begin{abstract}
Abstrak
Salah satu materi pembelajaran yang penting untuk dipelajari oleh siswa di Sekolah Dasar yaitu materi sejarah lokal. Kenyataannya sejarah lokal yang ada disekitar siswa belum menjadi sumber belajar yang dapat mendukung siswa memiliki pengetahuan lokal history. Untuk itu perlu dilakukan penelitian dan pengembangan untuk menghasilkan media audio visual situs peninggalan sejarah kolonialisme Inggris di Kota Bengkulu. Penelitian ini dilaksanakan melalui prosedur sesuai dengan langkah - langkah dalam model pengembangan Borg \& Gall. Dari sepuluh langkah pada model ini, hanya dilaksanakan enam langkah saja mengingat efektifitas dan efisiensi pelaksanaan penelitian dan pengembangan (1) studi pendahuluan, (2) perencanaan, (3) pengembangan produk, (4) validasi produk, (5) revisi produk, dan (6) produk akhir. Instrumen pengumpulan data dalam penelitian ini, yaitu studi dokumen dan lembar validasi ahli. Hasil penelitian yang diperoleh dalam penelitian ini media audio visual situs peninggalan sejarah kolonialisme Inggris di Kota Bengkulu dapat dikembangkan di Kelas V pada tema 7 Peristiwa Dalam Kehidupan. Media audio visual yang dikembangkan berupa video pembelajaran. Dari hasil uji validasi ahli teknologi pendidikan, pada kelayakan aspek materi diperoleh skor 94,44\%, sedangkan kelayakan aspek media memperoleh skor sebesar 94,56\%. Dari hasil penelitian ini dapat dikatakan bahwa media audio visual yang dikembangkan dinyatakan sangat valid dan dapat digunakan dalam pembelajaran.
\end{abstract}

Kata Kunci: Media Audio Visual, Sejarah Lokal, Kolonialisme Inggris, Sekolah Dasar.

\begin{abstract}
One of the essential learning materials for elementary school students to learn is the local history. The local history around students has not become a source of learning that can support students' local knowledge of history. For this reason, it is necessary to conduct research and development to produce audiovisual media for historical heritage sites of British colonialism in Bengkulu City. This research was carried out through procedures according to the steps in the Borg \& Gall development model. The data collection instruments in this study were document studies and expert validation sheets. The research results obtained in this study, audiovisual media can be developed in the 7th theme for the 5th-grade elementary students. Audiovisual media is produced in the form of learning videos. From the validation test results of educational technology experts, the feasibility of the material aspect obtained a score of $94.44 \%$. In comparison, the feasibility of the media aspect received a score of $94.56 \%$. From the results of this study, it can be said that the audiovisual media developed was declared to be very valid and could be used in learning.
\end{abstract}

Keywords: audiovisual media.Local History, British colonialism, Elementary School.

Copyright (c) 2021 Panut Setiono, Atika Susanti, Nabila Khansa Putri, Mufidah Mahdiyah, Anis Fahmi Andini

$\triangle$ Corresponding author

Email : setiono.pgsd@unib.ac.id

DOI : https://doi.org/10.31004/edukatif.v3i6.1589 
5006 Pengembangan Media Audio Visual Situs Peninggalan Sejarah Kolonialisme Inggris di Kota Bengkulu untuk Siswa Sekolah Dasar - Panut Setiono, Atika Susanti, Nabila Khansa Putri, Mufidah Mahdiyah, Anis Fahmi Andini

DOI: https://doi.org/10.31004/edukatif.v3i6.1589

\section{PENDAHULUAN}

Salah satu muatan pembelajaran (mata pelajaran) yang diajarkan pada pembelajaran tematik terpadu kurikulum 2013 di tingkat Sekolah Dasar (SD) adalah Ilmu Pengetahuan Sosial (IPS). Ruang lingkup materi yang diajarkan kepada peserta didik salah satunya adalah materi terkait dengan sejarah lokal yang ada di lingkungan sekitar (Tati, 2016) (Tasrif, 2008). Tujuannya sebagai fungsi untuk mendidik peserta didik yang terintegrasi masyarakat (Wijayanti, 2017). Sejarah lokal dapat digunakan sebagai materi pembelajaran IPS SD karena peserta didik tidak dapat dilepaskan dari proses sejarah masa lalu yang ada di lingkungannya. Selain itu, melalui pembelajaran sejarah lokal ini juga dapat digunakan sebagai upaya melestarikan dan mewariskan budaya dari generasi sebelumnya kepada generasi berikutnya.

Sejarah lokal merupakan sejarah yang berada di lingkungan wilayah terbatas (Hariyono, 2017) (Supardi, 2006). Banyak situs-situs peninggalan sejarah yang ada di Kota Bengkulu, terutama masa penjajahan Inggris yang terjadi di wilayah Bengkulu. Kolonialisme Inggris yang terjadi selama kurun waktu 1811 - 1816 (Hapsari \& Ridayanti, 2019) ini telah meninggalkan jejak sejarah yang dapat dimanfaatkan yang tidak hanya untuk rekreasi dan wisata, tetapi juga untuk tujuan pendidikan. Dengan memanfaatkan situs peninggalan sejarah lokal Bengkulu ini, peserta didik akan diarahkan pada peningkatan pemahaman tentang sejarah masa kolonialisme sebelum kemerdekaan serta upaya melestarikan situs peninggalan sejarah agar terus dapat dinikmati secara rekreatif dan dimanfaatkan untuk tujuan pendidikan pada generasi dimasa yang akan datang. Pembelajaran sejarah lokal ini juga dapat memberikan kontribusi untuk pembentukan pemahaman lokal history dalam usaha mendekatkan diri pada situasi riil yang terdekat dengan kehidupannya (Kusnoto \& Minandar, 2017).

Dewasa ini pembelajaran IPS di Sekolah Dasar belum berjalan sesuai yang diharapkan (Setiono, 2016), pembelajaran yang berlangsung cenderung membosankan (Ratnawati, 2016) dan dominasi guru dalam pembelajaran menyebabkan kecenderungan siswa menjadi pasif (Suprantini et al., 2017). Dampak yang ditimbulkan, prestasi belajar dan minat belajar IPS menjadi rendah. Padahal, jika pembelajaran dilaksanakan dengan melibatkan peserta didik (student centered) dalam proses pembelajaran, permasalahan seperti disampaikan diatas tidak akan terjadi. Selain factor siswa, Dengan adanya penyajian materi yang menarik, diharapkan ada pengaruh positif pada siswa untuk mempelajari materi sejarah lokal ini (Rohmadi \& Kurniawan, 2017).

Dari hasil observasi pra-penelitian yang dilakukan pada beberapa Sekolah Dasar yang ada di Kota Bengkulu, masih belum tersedia media pembelajaran berbasis situs sejarah lokal yang ada di Kota Bengkulu. Terutama di masa pandemi seperti saat ini, waktu untuk guru mengajar banyak berkurang, sehingga beberapa materi tidak dapat disampaikan secara maksimal. Selain itu, siswa juga tidak cukup memiliki sumber belajar yang sesuai dengan materi pembelajaran untuk dipelajari (Muthoharoh, 2021). Sejauh ini, proses pembelajaran IPS pada umumnya dilakukan dengan memanfaatkan buku teks dan slide power point, jika pun menggunakan video pembelajaran, yang digunakan adalah video peninggalan sejarah di Indonesia yang diperoleh dengan mengunduh dari situs Youtube. Sehingga kinerja akademik dalam proses pembelajaran IPS belum optimal. Untuk meningkatkan kualitas proses pembelajaran ini, maka perlu dikembangkan media audiovisual yang dapat mendukung peningkatan kualitas pembelajaran di Sekolah Dasar.

Pemanfaatan media pembelajaran audio visual relevan untuk meningkatkan hasil belajar pada pembelajaran muatan IPS di SD (Isnaeni \& Radia, 2021). Media pembelajaran audio visual adalah media perantara yang penyerapannya melalui pandangan dan pendengaran sehingga membangun kondisi yang dapat membuat siswa mampu memperoleh pengetahuan, keterampilan, atau sikap yang dipergunakan untuk membantu tercapainya tujuan belajar (Hayati \& Harianto, 2017). Penggunaan media Media audio-visual juga mampu membangkitkan ketertarikan siswa untuk mempelajari seni budaya. Rasa ketertarikan telah 
5007 Pengembangan Media Audio Visual Situs Peninggalan Sejarah Kolonialisme Inggris di Kota Bengkulu untuk Siswa Sekolah Dasar - Panut Setiono, Atika Susanti, Nabila Khansa Putri, Mufidah Mahdiyah, Anis Fahmi Andini

DOI: https://doi.org/10.31004/edukatif.v3i6.1589

membangkit rasa kemandirian siswa itu sehingga partisipasi aktif siswa dalam proses pembelajaran juga meningkatkan dengan sendirinya (Oktira et al., 2013). Media audio visual juga dapat meningkatkan hasil belajar kognitif siswa di Sekolah Dasar (Chrismawati et al., 2021).

Mengingat pentingnya pembelajaran yang menjadikan sejarah lokal yang disajikan secara menarik melalui media audio visual sebagai sumber belajar pada proses pembelajaran di SD, maka penelitian ini akan mengembangkan media audio visual situs peninggalan sejarah kolonialisme Inggris di Kota Bengkulu untuk siswa sekolah dasar. Hasil penelitian (Amalia et al., 2013) dan (Mardiani, 2018) menyatakan bahwa pengembangan media audiovisual pada pembelajaran sejarah lokal telah terbukti meningkatkan prestasi belajar peserta didik. Demikian juga media pembelajaran sejarah lokal ini dapat dimanfaatkan selama pelaksanaan pembelajaran dalam jaringan bagi peserta didik yang berasal dari luar daerah serta mengenalkan sejarah lokal kepada peserta didik (Bastaman \& Suwardi, 2020). Melalui produk yang dikembangkan ini, juga dapat dijadikan sebagai sumber belajar sejarah (Syaputra et al., 2020).

Mengacu pada uraian di atas, penelitian dan pengembangan yang dilakukan bertujuan untuk mengetahui proses pengembangan dan kevalidan media audiovisual peninggalan sejarah lokal yang berbeda dengan penelitian sebelumnya. Jika pengembangan sebelumnya dilakukan pada siswa tingkat SMA dan perguruan tinggi, penelitian ini akan dilakukan pada proses pembelajaran tematik terpadu untuk siswa SD. Situs peninggalan sejarah yang dijadikan sebagai materi pembelajaran juga berbeda, karena berasal dari sejarah lokal peninggalan kolonialisme Inggris.

\section{METODE PENELITIAN}

Metode penelitian yang dipilih dalam penelitian ini yaitu Research and Development $(R \& D)$ model Borg \& Gall. Model Borg \& Gall sendiri memiliki 10 langkah yang harus ditempuh, namun dalam penelitian ini langkah - langkah tersebut disederhanakan berdasarkan model penelitian Cunningham \& Gall, dkk (2003:573), menjadi enam langkah, yaitu: (1) studi pendahuluan, (2) perencanaan, (3) pengembangan produk, (4) validasi produk, (5) Revisi Produk, dan (6) produk akhir. Model pengembangan ini dipilih karena memiliki langkah-langkah yang mencerminkan pada pengembangan sebuah produk. Prosedur pengembangan yang dilakukan dalam penelitian ini dapat dilihat pada gambar 1 di bawah ini.

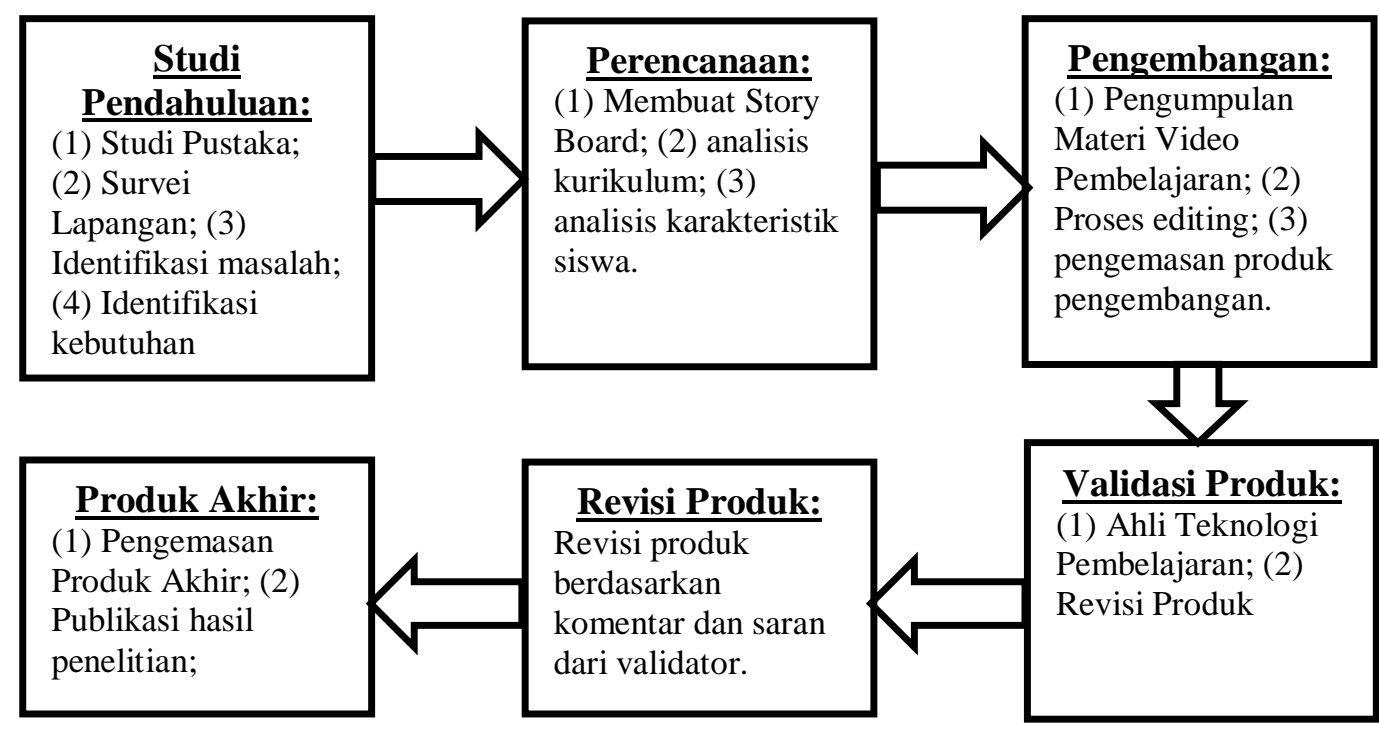

Gambar 1: Prosedur Model Pengembangan Borg \& Gall 
5008 Pengembangan Media Audio Visual Situs Peninggalan Sejarah Kolonialisme Inggris di Kota Bengkulu untuk Siswa Sekolah Dasar - Panut Setiono, Atika Susanti, Nabila Khansa Putri, Mufidah Mahdiyah, Anis Fahmi Andini

DOI: https://doi.org/10.31004/edukatif.v3i6.1589

Instrumen pengumpulan data dalam penelitian ini yaitu studi dokumen dan lembar validasi ahli. Studi dokumen dilakukan sebagai rujukan dalam melaksanakan analisis kurikulum proses pengembangan video. Telaah dokumen yang dilakukan pada Permendikbud Nomor 22 tahun 2016 Tentang standar proses dan Permendikbud Nomor 24 tahun 2016 tentang standar Kompetensi Inti dan Kompetensi Dasar Pelajaran Pada Kurikulum 2013 Pada Pendidikan Dasar dan Pendidikan Menengah. Sedangkan lembar validasi ahli digunakan untuk mendapatkan respon dari ahli pengembangan teknologi pendidikan untuk mendapatkan kriteria kevalidan berdasarkan desain media dan materi yang dikembangkan. Analisis data kelayakan produk pengembangan dilakukan dengan dianalisis dengan deskriptif presentase, dengan rumus (Akbar dan Sriwiyana, 2011:208):

$$
V=\frac{T S E V}{S-\max } \times 100 \%
$$

Selanjutnya diberikan penafsiran dan pengambilan keputusan tentang kelayakan produk pengembangan dengan menggunakan konversi tingkat pencapaian dengan skala Likert (Riduwan, 2010:89) yang dinyatakan pada table di bawah ini.

Tabel 1 Konversi Tingkat Kelayakan Produk

\begin{tabular}{lll}
\hline Tingkat Pencapaian & Kualifikasi & Keterangan \\
\hline $81 \%-100 \%$ & Sangat layak & Dapat digunakan tanpa revisi \\
\hline $61 \%-80 \%$ & Layak & Dapat digunakan dengan revisi \\
\hline $41 \%-60 \%$ & Cukup layak & Dapat digunakan dengan revisi \\
\hline $21 \%-40 \%$ & Kurang layak & Tidak dapat digunakan \\
\hline $0 \%-20 \%$ & Sangat kurang layak & Terlarang untuk digunakan \\
\hline \multicolumn{2}{c}{ Sumber: Riduwan (2010) }
\end{tabular}

\section{HASIL DAN PEMBAHASAN PENELITIAN}

Pada bagian ini akan dijelaskan tahapan kegiatan pengembangan produk sesuai dengan langkah-langkah pada model Borg \& Gall, yang meliputi tahap: (a) studi pendahuluan, (b) perencanaan, (c) pengembangan produk, (d) validasi produk, (e) Revisi Produk, dan (f) produk akhir.

\section{Studi Pendahuluan}

Pada tahap ini dilakukan Focus Group Discussion (FGD) bersama dengan Guru Kelas dari beberapa SD di Kota Bengkulu untuk mengumpulkan informasi. Hasil wawancara mendapatkan informasi bahwa beberapa sekolah memiliki fasilitas teknologi seperti lab komputer dan LCD, namun pemanfaatannya masih kurang. Wawancara juga dilakukan dengan guru kelas untuk mendapatkan informasi mengenai pelajaran yang dianggap sulit dan tidak menyenangkan. Hasil wawancara dengan guru kelas diketahui bahwa pelajaran tematik terpadu yang dianggap sulit dan tidak menyenangkan yaitu muatan pelajaran IPS, karena materi pembelajarannya banyak, sehingga kegiatan pembelajaran banyak memerlukan hafalan dan mencatat. Karakteristik siswa kelas V beberapa SD di Kota Bengkulu juga diidentifikasi, rata-rata siswa kelas V suka pelajaran yang berkaitan dengan hal-hal baru, mereka suka pelajaran yang tidak monoton.

Pada kegiatan studi pustaka, peneliti melakukan pengajian terhadap literatur untuk rujukan tentang pengembangan multimedia. Studi pustaka dilakukan untuk mengetahui berbagai informasi dan teori yang mendasari pembuatan video pembelajaran. Studi pustaka tersebut kemudian dijadikan dasar teoritik produk yang akan dikembangkan. Adapun studi pustaka yang dilakukan yaitu mempelajari kurikulum, konsep pembelajaran IPS di Sekolah Dasar, pendekatan pembelajaran IPS di Sekolah Dasar. 
5009 Pengembangan Media Audio Visual Situs Peninggalan Sejarah Kolonialisme Inggris di Kota Bengkulu untuk Siswa Sekolah Dasar - Panut Setiono, Atika Susanti, Nabila Khansa Putri, Mufidah Mahdiyah, Anis Fahmi Andini

DOI: https://doi.org/10.31004/edukatif.v3i6.1589

Kegiatan survei lapangan dilakukan di salah satu kelas V SD Negeri di Kota Bengkulu. Pada kegiatan ini peneliti melakukan observasi pelaksanaan pembelajaran IPS di dalam kelas, metode yang digunakan serta bahan ajar yang digunakan. Pada waktu pembelajaran di dalam kelas guru menggunakan metode synchronous, dengan menggunakan aplikasi whats up group sebagai media. Materi pembelajaran diberikan guru dengan memberikan penjelasan berupa teks (chat) kepada siswa, sedangkan penugasannya guru menggunakan media berupa poto, sesekali siswa diminta dating ke sekolah untuk mengambil LKPD. Kegiatan survei lapangan diikuti dengan mengidentifikasi masalah yang muncul pada muatan pembelajaran IPS. Masalah yang ditemukan peneliti saat melakukan survei lapangan di sekolah tersebut antara lain: (a) banyak siswa yang tidak suka dengan pelajaran IPS, (b) pembelajaran IPS merupakan pelajaran yang membosankan, (c) siswa cenderung kurang aktif saat pelajaran IPS, dan (d) nilai siswa cenderung kurang bagus saat pembelajaran IPS.

Setelah melakukan identifikasi masalah, selanjutnya peneliti mengidentifikasi kebutuhan yang harus segera terpenuhi di beberapa SD Negeri di Kota Bengkulu. Berdasarkan beberapa masalah di atas, maka peneliti mengusulkan mengembangkan media audio visual berupa video pembelajaran untuk mengatasi masalah tersebut.

\section{Perencanaan}

Pada tahap perencanaan kegiatan yang dilakukan melakukan analisi kurikulum dan analisis pembelajaran. Analisis kurikulum meliputi penentuan tema pembelajaran, pengembangan sub-tema pembelajaran, penentuan kompetensi dasar, pengembangan indikator pembelajaran, tujuan pembelajaran dan penetapan materi pembelajaran. Sedangkan analisis pembelajaran akan menetapkan strategi pembelajaran yang akan digunakan, meliputi pendekatan, model dan metode pembelajaran.

Tema dan sub-tema pembelajaran ditetapkan berdasarkan kesesuaian rencana penelitian pengembangan yang akan dilakukan. Dalam implementasi pembelajaran tematik terpadu menggunakan media audiovisual berbasis situs peninggalan sejarah lokal Bengkulu akan dilaksanakan di Kelas 5 pada tema 7 yaitu: Peristiwa Dalam Kehidupan. Tema ini tepat dijadikan sebagai dasar pengembangan materi pembelajaran peninggalan sejarah lokal Kota Bengkulu, sebab penjajahan oleh Inggris termasuk dalam peristiwa dalam kehidupan pada masa lampau. Setelah tema ditetapkan,selanjutnya dilakukan pengembangan sub-tema yang sesuai dengan rencana penelitian dan pengembangan. Sub-tema yang dikembangkan ini berbeda dengan subtema yang dikembangkan dalam buku siswa, tujuannya agar terdapat variasi pengembangan kurikulum pembelajaran tematik terpadu di sekolah dasar.

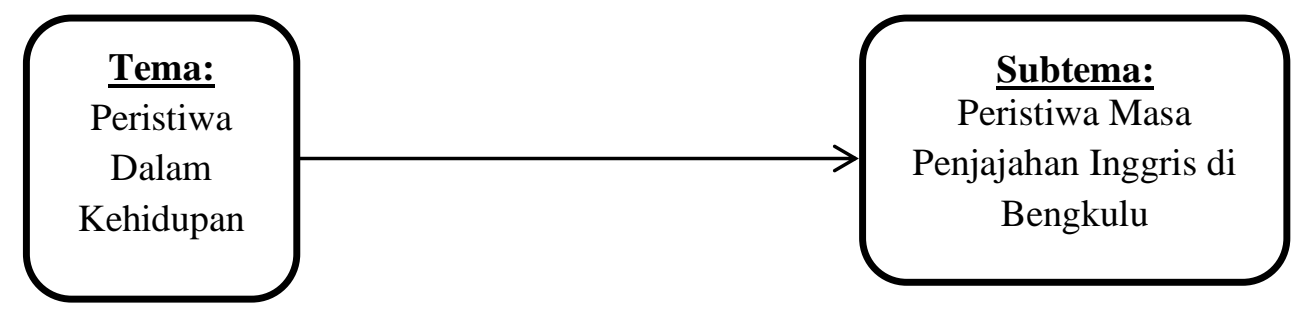

Gambar 2: Pengembangan Tema Menjadi Sub-Tema

Setelah sub-tema ditetapkan, selanjutnya dilakukan analisis kesesuaian Kompetensi Dasar, Indikator Pencapaian Kompetensi, dan Tujuan Pembelajaran. Analisis Kompetensi Dasar didasarkan pada Peraturan Menteri Pendidikan dan Kebudayaan Nomor 24 Tahun 2016 tentang Struktur Kurikulum Pendidikan Dasar Dan Menengah. Hasil analisis yang telah dilakukan dapat dilihat pada tabel 2 di bawah ini. 
5010 Pengembangan Media Audio Visual Situs Peninggalan Sejarah Kolonialisme Inggris di Kota Bengkulu untuk Siswa Sekolah Dasar - Panut Setiono, Atika Susanti, Nabila Khansa Putri, Mufidah Mahdiyah, Anis Fahmi Andini

DOI: https://doi.org/10.31004/edukatif.v3i6.1589

Tabel 2. Pemetaan Kompetensi Dasar, Indikator Pencapaian Kompetensi, dan Tujuan Pembelajaran

\begin{tabular}{|c|c|c|c|}
\hline No & $\begin{array}{l}\text { Kompetensi } \\
\text { Dasar }\end{array}$ & $\begin{array}{c}\text { Indikator Pencapaian } \\
\text { Kompetensi }\end{array}$ & Tujuan Pembelajaran \\
\hline & $\begin{array}{l}\text { IPS: } \\
3.4 \\
\text { Mengidentifikasi } \\
\text { faktor-faktor } \\
\text { penting penyebab } \\
\text { penjajahan bangsa } \\
\text { Indonesia dan } \\
\text { upaya bangsa } \\
\text { Indonesia dalam } \\
\text { mempertahankan } \\
\text { kedaulatannya. }\end{array}$ & $\begin{array}{l}\text { 1. Menyebutkan } \\
\text { negara yang } \\
\text { melakukan penjajahan } \\
\text { di Indonesia. } \\
\text { 2. Menyebutkan } \\
\text { peninggalan sejarah } \\
\text { penjajahan di } \\
\text { Indonesia } \\
\text { 3. Mengidentifikasi } \\
\text { faktor penting } \\
\text { penyebab penjajahan } \\
\text { Bangsa Indonesia. } \\
\text { 4. Menyimpulkan } \\
\text { penjajahan bangsa } \\
\text { Indonesia beserta } \\
\text { peninggalan } \\
\text { sejarahnya. }\end{array}$ & $\begin{array}{l}\text { 1. Setelah melihat Setelah melihat } \\
\text { tayangan video peninggalan sejarah di } \\
\text { Kota Bengkulu, siswa mampu } \\
\text { menyebutkan negara yang melakukan } \\
\text { penjajahan di Indonesia di Wilayah Kota } \\
\text { Bengkulu dengan benar. } \\
\text { 2.Setelah melihat tayangan video } \\
\text { peninggalan sejarah di Kota Bengkulu, } \\
\text { siswa mampu menyebutkan peninggalan } \\
\text { sejarah penjajahan di Indonesia dengan } \\
\text { benar. } \\
\text { 3. Setelah melihat tayangan video } \\
\text { peninggalan sejarah di Kota Bengkulu, } \\
\text { siswa mampu mengidentifikasi faktor } \\
\text { penting penyebab penjajahan Bangsa } \\
\text { Indonesia di Provinsi Bengkulu dengan } \\
\text { benar. } \\
\text { 4. Siswa mampu membuat kesimpulan } \\
\text { penjajahan bangsa Indonesia beserta } \\
\text { peninggalan sejarahnya dengan peta } \\
\text { konsep dengan tepat. }\end{array}$ \\
\hline
\end{tabular}

4.4 Menyajikan

hasil identifikasi

mengenai faktor-

faktor penting

penyebab

penjajahan bangsa

Indonesia dan

upaya bangsa

Indonesia dalam

mempertahankan

kedaulatannya.
1. Menyajikan hasil identifikasi mengenai

faktor penting penyebab penjajahan Bangsa Indonesia
1. Setelah melihat tayangan video peninggalan sejarah di Kota Bengkulu, siswa mampu membacakan hasil kesimpulan tentang faktor penting penyebab penjajahan Bangsa Indonesia dengan benar.

Matematika:

3.6 Menjelaskan dan menemukan jaring-jaring bangun ruang sederhana (kubus dan balok) 4.6 Membuat jaring-jaring bangun ruang sederhana (kubus dan balok)
Menganalisis jarringjaring balok.
Setelah melihat tayangan video peninggalan sejarah di Kota Bengkulu, siswa mampu menganalisis jarring-jaring balok pada salah satu peninggalan sejarah penjajahan bangsa Indonesia di wilayah Kota Bengkulu dengan benar.

Setelah melihat tayangan video peninggalan sejarah di Kota Bengkulu, siswa mampu menggambar jaring-jaring balok pada salah satu peninggalan sejarah penjajahan bangsa Indonesia di wilayah Kota Bengkulu dengan benar.

Bahasa Indonesia:

3.5 Menggali informasi penting Mampu menganalisis Setelah melihat tayangan video 
5011 Pengembangan Media Audio Visual Situs Peninggalan Sejarah Kolonialisme Inggris di Kota Bengkulu untuk Siswa Sekolah Dasar - Panut Setiono, Atika Susanti, Nabila Khansa Putri, Mufidah Mahdiyah, Anis Fahmi Andini

DOI: https://doi.org/10.31004/edukatif.v3i6.1589

\begin{tabular}{|c|c|c|c|}
\hline No & $\begin{array}{l}\text { Kompetensi } \\
\text { Dasar }\end{array}$ & $\begin{array}{c}\text { Indikator Pencapaian } \\
\text { Kompetensi }\end{array}$ & Tujuan Pembelajaran \\
\hline & $\begin{array}{l}\text { dari teks narasi } \\
\text { sejarah yang } \\
\text { disajikan secara } \\
\text { lisan dan tulis } \\
\text { menggunakan } \\
\text { aspek: apa, di } \\
\text { mana, kapan, } \\
\text { siapa, mengapa, } \\
\text { dan bagaimana }\end{array}$ & $\begin{array}{l}\text { informasi yang } \\
\text { disajikan secara lisan. }\end{array}$ & $\begin{array}{l}\text { peninggalan sejarah di Kota Bengkulu, } \\
\text { siswa mampu menganalisis informasi } \\
\text { tentang faktor penting penyebab } \\
\text { penjajahan Bangsa Indonesia di Provinsi } \\
\text { Bengkulu dengan benar. }\end{array}$ \\
\hline & $\begin{array}{l}\text { 4.5 Memaparkan } \\
\text { informasi penting } \\
\text { dari teks narasi } \\
\text { sejarah } \\
\text { menggunakan } \\
\text { aspek: apa, di } \\
\text { mana, kapan, } \\
\text { siapa, mengapa, } \\
\text { dan bagaimana } \\
\text { serta }\end{array}$ & $\begin{array}{l}\text { Mempresentasikan } \\
\text { informasi yang } \\
\text { disajikan secara lisan. }\end{array}$ & $\begin{array}{l}\text { Setelah melihat tayangan video } \\
\text { peninggalan sejarah di Kota Bengkulu, } \\
\text { siswa mampu mempresentasikan faktor } \\
\text { penting penyebab penjajahan Bangsa } \\
\text { Indonesia di Provinsi Bengkulu dengan } \\
\text { benar. }\end{array}$ \\
\hline & $\begin{array}{l}\text { PPKn: } \\
\text { 1.2 Menghargai } \\
\text { kewajiban, hak, } \\
\text { dan tanggug jawab } \\
\text { sebagai warga } \\
\text { masyarakat dan } \\
\text { umat beragama } \\
\text { dalam kehidupan } \\
\text { sehari-hari }\end{array}$ & $\begin{array}{l}\text { Menghargai } \\
\text { peninggalan sejarah. }\end{array}$ & $\begin{array}{l}\text { Setelah melihat tayangan video } \\
\text { peninggalan sejarah di Kota Bengkulu, } \\
\text { siswa mampu mempresentasikan faktor } \\
\text { penting penyebab penjajahan Bangsa } \\
\text { Indonesia di Kota Bengkulu dengan } \\
\text { benar. }\end{array}$ \\
\hline & $\begin{array}{l}2.2 \text { Menunjukkan } \\
\text { sikap tanggung } \\
\text { jawab dalam } \\
\text { memenuhi } \\
\text { kewajiban dan hak } \\
\text { sebagai warga } \\
\text { masyarakat dalam } \\
\text { kehidupan sehari- } \\
\text { hari }\end{array}$ & $\begin{array}{l}\text { Menunjukkan sikap } \\
\text { melestarikan } \\
\text { peninggalan sejarah. }\end{array}$ & $\begin{array}{l}\text { Setelah melihat tayangan video } \\
\text { peninggalan sejarah di Kota Bengkulu, } \\
\text { siswa mampu mempresentasikan faktor } \\
\text { penting penyebab penjajahan Bangsa } \\
\text { Indonesia di Kota Bengkulu dengan } \\
\text { benar. }\end{array}$ \\
\hline & $\begin{array}{l}\text { 3.2 Memahami } \\
\text { hak, kewajiban } \\
\text { dan tanggung } \\
\text { jawab sebagai } \\
\text { warga dalam } \\
\text { kehidupan sehari- } \\
\text { hari }\end{array}$ & $\begin{array}{l}\text { Menyebutkan sikap } \\
\text { yang dapat dilakukan } \\
\text { untuk melestarikan } \\
\text { peninggalan sejarah. }\end{array}$ & $\begin{array}{l}\text { Setelah melihat tayangan video } \\
\text { peninggalan sejarah di Kota Bengkulu, } \\
\text { siswa mampu Menyebutkan sikap yang } \\
\text { dapat dilakukan untuk melestarikan } \\
\text { peninggalan sejarah di Kota Bengkulu } \\
\text { dengan benar. }\end{array}$ \\
\hline & $\begin{array}{l}\text { 4.2 Menjelaskan } \\
\text { hak, kewajiban, } \\
\text { dan tanggung }\end{array}$ & $\begin{array}{l}\text { Menyampaikan secara } \\
\text { lisan sikap yang dapat } \\
\text { dilakukan untuk }\end{array}$ & $\begin{array}{l}\text { Setelah melihat tayangan video } \\
\text { peninggalan sejarah di Kota Bengkulu, } \\
\text { siswa mampu Menyampaikan secara lisan }\end{array}$ \\
\hline
\end{tabular}


5012 Pengembangan Media Audio Visual Situs Peninggalan Sejarah Kolonialisme Inggris di Kota Bengkulu untuk Siswa Sekolah Dasar - Panut Setiono, Atika Susanti, Nabila Khansa Putri, Mufidah Mahdiyah, Anis Fahmi Andini

DOI: https://doi.org/10.31004/edukatif.v3i6.1589

\begin{tabular}{|c|c|c|c|}
\hline No & $\begin{array}{l}\text { Kompetensi } \\
\text { Dasar }\end{array}$ & $\begin{array}{c}\text { Indikator Pencapaian } \\
\text { Kompetensi }\end{array}$ & Tujuan Pembelajaran \\
\hline & $\begin{array}{l}\text { jawab sebagai } \\
\text { warga masyarakat } \\
\text { dalam kehidupan } \\
\text { sehari-hari }\end{array}$ & $\begin{array}{l}\text { melestarikan } \\
\text { peninggalan sejarah. }\end{array}$ & $\begin{array}{l}\text { sikap yang dapat dilakukan untuk } \\
\text { melestarikan peninggalan sejarah di Kota } \\
\text { Bengkulu dengan benar. }\end{array}$ \\
\hline
\end{tabular}

Dari hasil analisis pengembangan indikator pencapaian kompetensi dan Tujuan pembelajaran di atas, materi pembelajaran yang akan dikembangkan yaitu: (1) Peninggalan Situs Sejarah Kolonialisme Inggris; (2) Informasi dari teks narasi sejarah; dan (3) Jaring-jaring balok. Strategi pembelajaran yang dapat diterapkan dalam pemanfaatan media video pembelajaran peninggalan situs sejarah kolonialisme inggris ini dapat dilakukan dengan penerapan model pembelajaran Contextual Teaching Learning (CTL) dan Project Based Learning (PjBL). Penggunaan model CTL digunakan untuk menambah kemampuan kognitif siswa dalam memahami sejarah, sedangkan model PjBL dilakukan untuk pengembangan hasil belajar aspek keterampilan peserta didik dalam belajar sejarah. Untuk Metode pembelajaran berupa ceramah, diskusi kelompok, demonstrasi, inkuiri, tanya jawab, dan penugasan individu.

\section{Pengembangan Produk}

Setelah tahap perencanaan dilakukan, selanjutnya dilakukan proses pengembangan produk berupa video pembelajaran. Untuk memudahkan proses kerja pengambilan video di lapangan, dibuatlah Story board (prototype produk yang dikembangkan). Story board yang dikembangkan meliputi rencana tampilan video pembelajaran yang terdiri dari bagian awal, bagian ini, dan bagian akhir video, termasuklah menetapakan rencana desain kegrafikan seperti sajian kombinasi teks, gambar dan video.

Setelah story board ditetapkan, tahapan selanjutnya melakukan pengambilan gambar dan video di lapangan. Tim mendatangi satu persatu situs peninggalan sejarah kolonialisme Inggris yang ada di Kota Bengkulu, yaitu:

1) Situs sejarah Benteng Marlborough yang beralamat di Jl. Benteng, Kebun Keling, Kec. Teluk Segara, Kota Bengkulu.

2) Situs sejarah Monumen Tugu Thomas Parr beralamat Malabero, Kec. Teluk Segara, Kota Bengkulu.

3) Situs sejarah Benteng York Kelurahan Pasar Bengkulu, Kecamatan Sungai serut, Kota Bengkulu.

4) Situs sejarah Komplek Makam Inggris, Jalan Veteran, Pasar. Jitra, Bengkulu, Kota Bengkulu.

5) Situs sejarah Robert Hamilton beralamat di Pasar Melintang, Kecamatan Teluk Segara, Kota Bengkulu, Bengkulu.

Proses pengembangan video pembelajaaran, dalam proses perekaman gambar dan video dilakukan dengan menggunakan perangkat teknologi yaitu kamera model Digital Single Lens Reflex (DSLR) merk Canon tipe EoS 1200D dan kamera Handphone merk Samsung tipe Galaxy A50S. Untuk mengisi suara dalam video menggunakan perekam pada Handphone merk Samsung tipe Galaxy A50S dengan bantuan Microphone Mic Clip On Boya BY-M1 Lavalier. Untuk proses editing video pembelajaran menggunakan software Filmora Pro Untuk Windows, Capcut for PC dan Inshot pak.

\section{Validasi Produk}

Pada tahap ini, validasi produk dilakukan pada para ahli yaitu ahli teknologi pendidikan. Validasi dari ahli diperlukan untuk menyempurnakan desain produk sebelum diberikan kepada siswa. Produk yang telah selesai dibuat, diserahkan pada ahli teknologi pendidikan untuk mengetahui kesesuaian materi dalam video pembelajaran dengan karakteristik siswa serta agar tampilan media sesuai dengan karakteristik siswa. Hasil uji 
5013 Pengembangan Media Audio Visual Situs Peninggalan Sejarah Kolonialisme Inggris di Kota Bengkulu untuk Siswa Sekolah Dasar - Panut Setiono, Atika Susanti, Nabila Khansa Putri, Mufidah Mahdiyah, Anis Fahmi Andini

DOI: https://doi.org/10.31004/edukatif.v3i6.1589

validasi kelayakan video berdasarkan aspek materi pembelajaran dilakukan dengan memberikan lembar validasi dan video pembelajaran yang telah dikembangkan kepada validator. Yang menjadi validator ini yaitu Dr. Eko Risdianto, M.Cs. yang memiliki pengalaman dalam bidang pengajaran, penelitian dan pengabdian kepada masyarakat tentang pengembangan media pembelajaran berbasis teknologi.

Dari hasil uji validasi berdasarkan kelayakan materi yang disajikan, secara keseluruhan mendapatkan skor 94,44\%. Dari perolehan skor tersebut, setelah dikonversi pada tabel konversi kelayakan produk, mendapatkan kriteria Sangat layak dengan kriteria dapat interpretasi produk yang dikembangkan dapat digunakan tanpa revisi. Selengkapnya hasil uji validasi kelayakan aspek materi dapat dilihat pada tabel 3 di bawah ini.

Tabel 3. Hasil Uji Validasi Kelayakan Aspek materi

\begin{tabular}{clcc}
\hline No & Kriteria kelayakan & Skor Perolehan & \multirow{2}{*}{ Rata - rata Skor } \\
\cline { 1 - 2 } 1 & Tinjauan Materi & $95,83 \%$ & \multirow{2}{*}{$94,44 \%$} \\
\cline { 1 - 2 } 2 & Pengembangan kemampuan Literasi Sejarah & $87,5 \%$ & \\
\cline { 1 - 2 } 3 & Pengembangan kemampuan Berpikir Kritis & $100 \%$ & \\
\hline
\end{tabular}

Dari tabel di atas dapat dilihat bahwa untuk uji validasi kelayakan aspek materi dapat lihat pada indikator tinjauan materi mendapatkan skor $95,83 \%$, indikator pengembangan kemampuan literasi sejarah mendapatkan skor $87,5 \%$, dan indikator pengembangan kemampuan berpikir kritis mendapatkan skor sebesar $100 \%$.

Hasil uji validasi kelayakan aspek media yang dilakukan dapat dilihat pada tabel 4, di bawah ini.

Tabel 4. Hasil Uji Validasi Kelayakan Apsek Media

\begin{tabular}{clcc}
\hline No & Kriteria kelayakan & Skor Perolehan & Rata - rata Skor \\
\hline 1 & Efisiensi dan Efektivitas & $95,0 \%$ & \multirow{2}{*}{$94,56 \%$} \\
\cline { 1 - 2 } 2 & Tampilan Penyajian & $92,85 \%$ & \\
\hline 3 & Kualitas Teknis/Kemudahan Penggunaan Media & $95,83 \%$ & \\
\hline
\end{tabular}

\section{Revisi Produk}

Video pembelajaran yang telah direvisi sesuai dengan masukan dari ahli media dan ahli materi, kemudian diuji cobakan dengan skala terbatas pada guru dan siswa kelas V SDN 74 Kota Bengkulu. Pada tahap ini akan dilakukan dua tahap uji coba yaitu uji coba kelompok kecil dan uji coba perorangan. Uji coba dilakukan untuk mengukur tingkat kepraktisan, keefektifan, dan kemenarikan produk. Catatan perbaikan yang diberikan oleh validator untuk direvisi dapat dilihat pada tabel di bawah ini.

Tabel 5. Catatan Validator

\begin{tabular}{|c|c|c|c|}
\hline No. & Capture Tampilan pada Video & Saran Perbaikan & Perbaikan yang dilakukan \\
\hline 1 & & $\begin{array}{l}\text { Video sudah sangat baik } \\
\text { namun beberapa } \\
\text { Pergerakan pada Sceen } \\
\text { Video nanti diharapkan } \\
\text { lebih smooth lagi. Untuk } \\
\text { pengambilan video } \\
\text { disarankan dengan } \\
\text { menggunakan perangkat } \\
\text { video yang memiliki } \\
\text { penstabil video }\end{array}$ & $\begin{array}{l}\text { Perbaikan Sceen video sudah } \\
\text { dilakukan melalui proses } \\
\text { editing pada software video } \\
\text { editor. }\end{array}$ \\
\hline
\end{tabular}


5014 Pengembangan Media Audio Visual Situs Peninggalan Sejarah Kolonialisme Inggris di Kota Bengkulu untuk Siswa Sekolah Dasar - Panut Setiono, Atika Susanti, Nabila Khansa Putri, Mufidah Mahdiyah, Anis Fahmi Andini

DOI: https://doi.org/10.31004/edukatif.v3i6.1589

\begin{tabular}{llll}
\hline No. & Capture Tampilan pada Video & Saran Perbaikan & Perbaikan yang dilakukan \\
\hline 2 & Kualitas Video secara & $\begin{array}{l}\text { Perbaikan dilakukan dengan } \\
\text { umum sangat baik namun } \\
\text { meningkatkan pengaturan } \\
\text { beberapa scene kualitas } \\
\text { video berbeda beda yang } \\
\text { mungkin dikarenakan } \\
\text { melalui video editor. }\end{array}$ \\
& & $\begin{array}{l}\text { diambil melalui perangkat } \\
\text { yang berbeda beda. }\end{array}$ & \\
& &
\end{tabular}

\section{Produk Akhir}

Produk penelitian dan pengembangan yang sudah direvisi selanjutnya dikembalikan kepada validator untuk review kembali, apakah catatan dan saran yang diberikan oleh validator sudah dilaksanakan dan sesuai. Setelah direview video pembelajaran yang sudah direvisi sudah dapat digunakan dalam proses pembelajaran untuk siswa. Untuk memudahkan penyebar luasan, video pembelajaran ini akan disimpan dalam di unggah ke You Tube. https://www.youtube.com/watch?v=Qz8egvK5QZE yang dapat diakses secara bebas oleh siswa.

Hasil penelitian dan pengembangan media audiovisual situs peninggalan sejarah kolonialisme Inggris di Kota Bengkulu ini sejalan dengan hasil penelitian (Zahroh, 2016) yang menghasilkan media audio visual berbasis sejarah lokal yang layak digunakan berdasarkan hasil uji validasi ahli dan siswa. Demikian juga hasil penelitian (Amalia et al., 2014) media audio visual yang berbasis peristiwa sejarah lokal mendapatkan kriteria baik setelah dilakukan validasi oleh ahli materi dan ahli media. Dari hasil tersebut dapat dinyatakan bahwa dalam penelitian ini maupun penelitian sebelumnya, media audiovisual merupakan sumber belajar yang dapat dimanfaatkan oleh peserta didik untuk tujuan pelestarian peninggalan sejarah agar tidak dirusak yang dapat menghilangkan bukti sejarah yang pernah terjadi. Adanya produk pengembangan ini dapat memudahkan guru mengajarkan materi berupa konsep - konsep sejarah.

Produk yang dikembangkan memiliki kelebihan yang tidak dimiliki oleh media audiovisual sebelumnya, sebab materi pembelajaran yang dikembangkan merupakan situs peninggalan sejarah kolonialisme Inggris yang ada di Kota Bengkulu. Peninggalan sejarah ini tentu saja hanya ada di Kota Bengkulu dan tidak dimiliki oleh daerah lain di Indonesia, misalnya saja Benteng Marlborough, juga makam Inggris. Produk yang dikembangkan juga telah memenuhi kriteria pemanfaatan sumber belajar yang berasal dari lingkungan terdekat peserta didik dan sesuai dengan karakteristik penggunanya. Namun demikian, produk yang telah dikembangkan masih perlu dilakukan uji coba dalam tahap lebih luas lagi, misalnya saja untuk peserta didik di kabupaten lain di Provinsi Bengkulu. Media audiovisual ini juga perlu dilengkapi dengan perangkat pembelajaaran yang sesuai dengan tuntutan kurikulum. Media audiovisual juga hendaknya dapat diperbaharui dalam bentuk lain seperti e-modul maupun multimedia interaktif agar adaptif dengan pemograman yang ada di gawai berbasis android maupun i-phone.

\section{KESIMPULAN}

Berdasarkan hasil penelitian dan pembahasan di atas, disimpulkan bahwa media audiovisual situs peninggalan sejarah kolonialisme Inggris di Kota Bengkulu dikembangkan dalam bentuk video pembelajaran. Materi ini dapat digunakan pada pembelajaran tematik terpadu di kelas V pada tema 7 Peristiwa Dalam Kehidupan. Materi ini dapat diintegrasikan pada muatan pembelajaran IPS, Bahasa Indonesia, Matematika dan Pendidikan Pancasila dan Kewarganegaraan. Dari hasil uji validasi ahli teknologi pendidikan, pada kelayakan aspek materi diperoleh skor 94,44\%, sedangkan kelayakan aspek media memperoleh skor sebesar 94,56\%. Dari hasil penelitian ini dapat dikatakan bahwa media audio visual yang dikembangkan dinyatakan 
5015 Pengembangan Media Audio Visual Situs Peninggalan Sejarah Kolonialisme Inggris di Kota Bengkulu untuk Siswa Sekolah Dasar - Panut Setiono, Atika Susanti, Nabila Khansa Putri, Mufidah Mahdiyah, Anis Fahmi Andini

DOI: https://doi.org/10.31004/edukatif.v3i6.1589

sangat valid dan dapat digunakan dalam pembelajaran. Penelitian lanjutan yang dapat dilakukan oleh penelitian berikutnya dapat menguji kelayakan video pembelajaran ini dalam proses pembelajaran untuk menguji keefektifan media audiovisual yang telah dikembangkan.

\section{UCAPAN TERIMA KASIH}

Ucapan terima kasih disampaikan kepada LPPM Universitas Bengkulu yang telah memberikan dana penelitian melalui skim penelitian pembinaan Tahun 2021.

\section{DAFTAR PUSTAKA}

Amalia, T. R., Wasino, \& Suryani, N. (2014). Pengembangan Media Pembelajaran Sejarah Menggunakan Audio Visual Berbasis Peristiwa Sejarah Lokal Di Madiun. Agasatya, 79-88.

Amalia, T. R., Wasino, W., \& Suryani, N. (2013). Pengembangan Media Pembelajaran Sejarah Menggunakan Audio Visual Berbasis Peristiwa Sejarah Lokal Di Madiun (Studi Pada Siswa Smp Di Kabupaten Madiun). Tesis Uns-Pascasarjana Prodi. Pendidikan Sejarah. Https://Digilib.Uns.Ac.Id/Dokumen/Detail/30945/Pengembangan-Media-Pembelajaran-Sejarah-

Menggunakan-Audio-Visual-Berbasis-Peristiwa-Sejarah-Lokal-Di-Madiun-Studi-Pada-Siswa-Smp-Di-

Kabupaten-Madiun

Bastaman, W. W., \& Suwardi. (2020). Pengembangan Pembelajaran Sejarah Lokal Pada Masa Pandemi Covid-19. Jurnal Kala Manca, Https://Jurnal.Stkipsetiabudhi.Ac.Id/Index.Php/Kalamanca/Article/View/10

Chrismawati, M., Septiana, I., \& Purbiyanti, E. D. (2021). Peningkatan Hasil Belajar Melalui Model Flipped Classroom Berbantuan Media Power Point Dan Audio Visual Di Sekolah Dasar Mirna. Edukatif: Jurnal Ilmu Pendidikan, 3(5), 1928-2934.

Hapsari, K., \& Ridayanti, N. (2019). Layanan Akses Arsip Statis Di Arsip Nasional Ri. Subdirektorat Layanan Arsip, Direktorat Layanan Dan Pemanfaatan, Asip Nasional Ri.

Hariyono, H. (2017). Sejarah Lokal: Mengenal Yang Dekat, Memperluas Wawasan. Sejarah Dan Budaya: Jurnal Sejarah, Budaya, Dan Pengajarannya, 11(2), 160-166. Https://Doi.Org/10.17977/Um020v11i22017p160

Hayati, N., \& Harianto, F. (2017). Hubungan Penggunaan Media Pembelajaran Audio Visual Dengan Minat Peserta Didik Pada Pembelajaran Pendidikan Agama Islam Di Sman 1 Bangkinang Kota. Al-Hikmah: Jurnal Agama Dan Ilmu Pengetahuan, 14(2), 160-180. Https://Doi.Org/10.25299/AlHikmah:Jaip.2017.Vol14(2).1027

Isnaeni, R., \& Radia, E. H. (2021). Meta-Analisis Pengaruh Penggunaan Media Audio Visual Terhadap Hasil Belajar Ips Siswa Di Sekolah Dasar. Edukatif: Jurnal Ilmu Pendidikan, 3(2), 304-313. Https://Doi.Org/10.31004/Edukatif.V3i2.281

Kusnoto, Y., \& Minandar, F. (2017). Pembelajaran Sejarah Lokal : Pemahaman Kontens Bagi Mahasiswa. Sosial Horizon: Jurnal Pendidikan Sosial, $4(1), \quad 125-137$. Https://Journal.Ikippgriptk.Ac.Id/Index.Php/Sosial/Article/View/428

Mardiani, F. (2018). Pengembangan Media Pembelajaran Sejarah Lokal Berbasis Audio Visual Corak Kain Sasirangan Di Sman 5 Banjarmasin. Istoria: Jurnal Pendidikan Dan Sejarah, 14(1). Https://Doi.Org/10.21831/Istoria.V14i1.19399

Muthoharoh, F. C. (2021). Pengembangan Media Pembelajaran Berbasis Video Naratif Dengan Metakognitif Pada Materi Ketenagakerjaan Fitria Cholifatoul Muthoharoh. Edukatif: Jurnal Ilmu Pendidikan, 3(5), 2032-2039. 
5016 Pengembangan Media Audio Visual Situs Peninggalan Sejarah Kolonialisme Inggris di Kota Bengkulu untuk Siswa Sekolah Dasar - Panut Setiono, Atika Susanti, Nabila Khansa Putri, Mufidah Mahdiyah, Anis Fahmi Andini

DOI: https://doi.org/10.31004/edukatif.v3i6.1589

Oktira, Y. S., Ardipal, L, J., \& Toruan. (2013). Penggunaan Media Audio Visual Untuk Meningkatkan Kemandirian Siswa Belajar Seni Budaya. E-Jurnal Sendratasik Fbs Universitas Negeri Padang, 2(1), $63-68$.

Ratnawati, E. (2016). Pentingnya Pembelajaran Ips Terpadu. In Edueksos: Jurnal Pendidikan Sosial \& Ekonomi (Vol. 2, Issue 1). Https://Doi.Org/10.24235/Edueksos.V2i1.635

Rohmadi, \& Kurniawan, G. F. (2017). Pembelajaran Sejarah Lokal Berbasis Folklore Siswa. Sejarah Dan Budaya: Jurnal Sejarah, Budaya, Dan Pengajarannya, Xi(1), 79-94.

Setiono, P. (2016). Pemanfaatan Nilai Budaya Lokal Tari Topeng Malang Sebagai Bahan Ajar Untuk Siswa Kelas Iv Sekolah Dasar. In Jurnal Pendidikan Dan Pembelajaran Anak Sekolah Dasar (Vol. 1, Issue 02). Https://Doi.Org/10.29100/Jpsd.V1i02.173

Supardi, S. (2006). Pendidikan Sejarah Lokal Dalam Konteks Multikulturalisme. Jurnal Cakrawala Pendidikan, O(1), 117-138. Https://Doi.Org/10.21831/Cp.V0i1.395

Suprantini, E., Rohaetin, S., Oktobery, R., \& Ekonomi, P. P. (2017). Upaya Peningkatan Prestasi Belajar Ips Terpadu Melalui Pendekatan Komunitas Belajar Di Kelas Viii Smpn-3 Parenggean Tahun Pelajaran 2016/2017. Jurnal Pendidikan Ilmu Pengetahuan Sosial (Jpips) Desember, 2017(8), 21-28. Http://EJournal.Upr.Ac.Id/Index.Php/Jp-Ips

Syaputra, M. A. D., Sariyatun, S., \& Ardianto, D. T. (2020). Pemanfaatan Situs Purbakala Candi Muaro Jambi Sebagai Objek Pembelajaran Sejarah Lokal Di Era Digital. Jurnal Pendidikan Sejarah Indonesia, 3(1), 77-87. Https://Doi.Org/10.17977/Um0330v3i1p77-87

Tasrif, T. (2008). Pengantar Pendidikan Ilmu Pengetahuan Sosial. Genta Press.

Tati, A. D. R. (2016). Analisis Kebutuhan Bahan Ajar Muatan Lokal Sejarah Dan Budaya Kabupaten Bone Di Sekolah Dasar. Istoria: Jurnal Pendidikan Dan Ilmu Sejarah, 12(2). Https://Doi.Org/10.21831/Istoria.V12i2.11057

Wijayanti, Y. (2017). Peranan Penting Sejarah Lokal Dalam Kurikulum Di Sekolah Menengah Atas. Jurnal Artefak, 4(1), 53. Https://Doi.Org/10.25157/Ja.V4i1.735

Zahroh, N. L. (2016). Pengembangan Media Audio Visual Berbasis Sejarah Lokal Dalam Meningkatkan Kualitas Pembelajaran Ips Sd Di Kecamatan Singosari Kabupaten Malang. J-Pai: Jurnal Pendidikan Agama Islam, 2(2), 115-130. Https://Doi.Org/10.18860/Jpai.V2i2.3975 